\title{
SENSE OF GENERALISED SELF-EFFICACY AND PRO-HEALTH BEHAVIOURS OF POLISH AND SPANISH PHYSICAL EDUCATION STUDENTS
}

\author{
Maria Gacek, 1, A, C, D, E Grażyna Kosiba, 2, A, B, D, E Agnieszka Wojtowicz 3 , A, C, E \\ 1 University of Physical Education in Kraków, Faculty of Physical Education and Sport, Department of Sports Medicine and Human Nutrition, \\ Poland, \\ ${ }^{2}$ University of Physical Education in Kraków, Faculty of Physical Education and Sport, Department of Theory and Methodology of Physical \\ Education, Poland \\ ${ }^{3}$ University of Physical Education in Kraków, Faculty of Physical Education and Sport, Department of Psychology, Poland

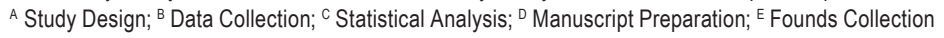 \\ Address for correspondence: \\ Maria Gacek \\ Department of Sports Medicine and Human Nutrition, Faculty of Physical Education and Sport, University of Physical Education in Kraków \\ Al. Jana Pawła II 79, 31-571 Kraków, Poland \\ E-mail: maria.gacek@awf.krakow.pl
}

\begin{abstract}
Ahstract The aim of the study was to assess the relationship between the sense of generalised self-efficacy and the level of prohealth behaviours among Polish and Spanish physical education students.

The study was conducted among 499 physical education students (219 Polish and 280 Spanish). The Inventory of Health Behaviours (IZZ) by Z. Juczyński and the Generalised Self-Efficacy Scale (GSES) by R. Schwarzer, M. Jerusalem and Z. Juczyński were used. Among the categories of healthy behaviours included in the Inventory of Health Behaviours (IZZ), the physical education students obtained the highest average results in the area of positive mental attitude (22.26), less in the prohealth practices (20.10) and proper eating habits (19.85), and less again in the area of preventive behaviours (18.97). Statistically significant positive correlations were found between the intensification of the generalised sense of self-efficacy and the levels of positive mental attitude $(p=0.024)$ and preventive behaviours $(p<0.001)$. The moderating influence regarding home country on relationships between the generalised sense of self-efficacy and general index of pro-health behaviours $(p=0.024)$ was also demonstrated; in the case of the Spanish students the level of pro-health behaviours increased, but for the Polish students it decreased.
\end{abstract}

Key Wordls pro-health behaviours, generalised self-efficacy, physical education students

\section{Introduction}

A pro-health lifestyle, e.g. rational food choices, physical activity, avoidance of psychoactive substances, constructive coping with stress, and implementing preventive behaviours, is the basic determinant of holistically defined health (WHO, 2004; Gray, 2017). In many countries, physical activity and a rational nutrition model as basic health-promoting behaviours have been included in the canon of basic aspects of a healthy lifestyle (http://www.fao. org/nutrition/education/food-dietaryguidelines/regions/europe/en). 
The key significance of lifestyle and pro-health behaviours requires health-oriented attitudes at all stages of ontogenesis, with particular emphasis on children and adolescents. Healthy behaviours, as behavioural determinants of health, are shaped in the process of socialisation as a result of the impact of norms and patterns functioning in a given environment. In this context, school health education (at all of its stages) is important, in which teachers of all specialisations, including physical education teachers, are involved. School health education aims to shape healthy attitudes in children and adolescents, along with positive attitudes towards behavioural determinants of health that affect the proper development of children and adolescents.

The effectiveness of teachers' work in the field of health education depends, inter alia, on their individual attitudes towards behavioural determinants of health. The importance of teachers' pro-health behaviours for shaping students' lifestyles has been confirmed, among others, in American, Chilean and Chinese studies (Rossiter, Glanville, Taylor, Blum, 2007; Findholt, Izumi, Shannon, Nguyen, 2016; Montenegro, Salinas, Parra, Lera, Vio, 2014; Chang, Liao, Chen, Niu, Hsieh, 2017). A health-conscious teacher is a more credible health educator, as indicated by the teachers themselves (Schee, Gard, 2014; Moynihan, Paakkari, Välimaa, Jourdan, Mannix-McNamara, 2015). Despite the key role of a healthy lifestyle in raising health potential, in numerous studies the prevalence of antihealth behaviours has been shown in the lifestyle of various population groups, including academic youth with a teaching educational profile (Deasy, Coughlan, Pironom, Jourdan, Mcnamara, 2015; Kosiba, Gacek, BogaczWalancik, Wojtowicz, 2016a; Monhollen, Summers, Sabin, Rutherford, 2016; Yahia, Wang, Rapley, Dey, 2016).

The implementation of health education by teachers has been recorded in the core-curriculum documents of many countries. In Poland, the role of a teacher in school health education has been included in the corecurriculum of general education (Journal of Laws 2017, Item 356) and in the educational standards preparing to perform the profession of a teacher (Journal of Laws of 2019, Item 1450). Also in Spain, in the decrees of autonomous communities, tasks related to shaping attitudes and behaviours conducive to health were included as objectives of general education (Decreto 97/2015 from $3^{\text {rd }}$ March).

Pro-health behaviours are determined by a wide spectrum of socioeconomic, cultural and personality-related factors (Remick, Polivy, Pliner, 2009). Among the psychological features important for the development of health culture, personal resources occupy an important place, including those related to a generalised sense of selfefficacy (Juczyński, 2012). Sense of self-efficacy, as a belief in the ability to achieve intended goals, is conducive to exercising control over behavioural factors conditioning holistically defined health (Juczyński, 2012). To date, research on the determinants of different areas of lifestyle among physical education students and of other teaching specialisations has concerned satisfaction with life (Kosiba, Gacek, Wojtowicz, Bogacz-Walancik, 2016b) and readiness for change (Kosiba, Gacek, Wojtowicz, 2019a).

The premise for undertaking the presented research was the assumption that health-related behaviours are a key determinant of health, and the personal resources of the subject play an important role in shaping them. The aim of the study was to assess the level of pro-health behaviours (according to the IZZ) together with the relationship between generalised sense of self-efficacy and the relationship to the intensity of pro-health behaviours, then to analyse the moderating importance of the country of origin in Polish and Spanish physical education students in relation to the examined correlations. 


\section{Materials and Methods}

The study was conducted in 2017-2019 among 499 physical education students aged 18 to $35(21.65 \pm 2.42)$ of second and third year B.A. degree studies. Research included 219 Polish students (University of Physical Education in Krakow, $n=135$, and the University of Physical Education in Wroclaw, $n=84$ ) as well as 280 Spanish students (University of Murcia, Faculty of Sport Sciences, $n=127$, and the University of Granada, Faculty of Sport Sciences, $n=153)$.

In the research, a diagnostic survey and two standardised research tools were used: the Inventory of Health Behaviours (IZZ) by Z. Juczyński, and the Generalised Self-Efficacy Scale (GSES) by R. Schwarzer, M. Jerusalem and Z. Juczyński (Juczyński, 2012). Based on the Inventory of Health Behaviours (IZZ), 4 categories of health behaviours (proper eating habits, preventive behaviours, pro-health practices, and positive mental attitude) and the general index of pro-health behaviours were assessed (Juczyński, 2012). To measure the sense of self-efficacy, the standardised Generalised Self-Efficiency Scale (GSES) by R. Schwarzer, M. Jerusalem and Z. Juczyński (Juczyński, 2012) was used. The GSES scale, containing 10 statements, is constructed in such a way that the higher the test result (within the range of 10-40 points), the higher the sense of generalised self-efficacy. Research was carried out in accordance with the principles of the 1964 Declaration of Helsinki after obtaining the subjects' informed consent to participate in the study.

The IBM SPSS 21 program and J.T. Newsom's macro were used for statistical calculations. Basic statistics of the studied variables were calculated (means and standard deviations). Pearson's correlation coefficient analysis was used to determine the relationships between variables, while moderation analysis with simple comparisons (simple slopes) was used to determine differences in the relationships between sense of self-efficacy and students' pro-health behaviours. The Student's $t$-test was applied to determine differences in the level of self-efficacy between students from Poland and Spain. The significance level of $\alpha=0.05$ was adopted.

\section{Results}

Among the categories of pro-health behaviours included in the Inventory of Health Behaviours (IZZ), the physical education students obtained the highest average results in the category of positive mental attitude (22.26). The value for pro-health practices was 20.10 and proper eating habits was 19.85 , while the value for preventive behaviours was 18.97 (Table 1).

Table 1. Level of pro-health behaviours among Polish and Spanish physical education students (descriptive statistics)

\begin{tabular}{lccccc}
\hline \multicolumn{1}{c}{ IZZ categories } & N & Minimum & Maximum & Mean & Standard deviation \\
\hline Positive mental attitude (PMA) & 499 & 10.0 & 30.0 & 22.26 & 3.62 \\
Preventative behaviours (PB) & 499 & 6.0 & 30.0 & 18.97 & 4.05 \\
Proper eating habits (PEH) & 499 & 6.0 & 30.0 & 19.85 & 5.01 \\
Pro-health practices (PHP) & 499 & 7.0 & 29.0 & 20.10 & 3.64 \\
\hline IZZ total & 499 & 15.0 & 113.0 & 50.27 & 29.14 \\
\hline
\end{tabular}


In the analysis, no statistically significant difference in the level of self-efficacy was shown between the students from Poland and Spain ( $t=-1.50 ; d f=497 ; p=0.134$ ).

The conducted analysis on the relationship between the generalised sense of self-efficacy and pro-health behaviours for the entire group of students showed that along with the increase in generalised sense of self-efficacy, the level of positive mental attitude and preventive behaviour of the studied physical education students increased (Table 2).

Table 2. Sense of generalised self-efficacy and pro-health behaviours among Polish and Spanish physical education students (Pearson's correlation coefficient)

\begin{tabular}{|c|c|c|c|c|c|c|}
\hline & & & & & & \\
\hline & & PMA & PB & PEH & PHP & IZZ total \\
\hline GSES & $R$ & $0.10^{\circ}$ & $0.160^{* *}$ & 0.070 & 0.020 & 0.030 \\
\hline & $p$ & 0.024 & $<0.001$ & 0.143 & 0.595 & 0.501 \\
\hline & $\mathrm{N}$ & 499 & 499 & 499 & 499 & 499 \\
\hline
\end{tabular}

${ }^{*} p<0.05 ; " \mathrm{p}<0.001$

Analysis was also conducted on how the relationship between the generalised sense of self-efficacy and the level of pro-health behaviours changes depended on the country of origin of the physical education students (Table 3). It has been shown that the country of origin may be considered as a moderator of the relationship of selfefficacy with the overall indicator of pro-health practices. Among the physical education students from Spain, the higher the level of generalised sense of self-efficacy, the higher the general level of pro-health behaviours, while among the students from Poland this relationship was negative, i.e. along with the increase in self-efficacy, the general level of pro-health behaviours decreased (Figure 1).

Table 3. Moderation analysis - moderating variable: country; independent variable: GSES

\begin{tabular}{|c|c|c|c|c|c|c|c|}
\hline Ind. var. & Moderator & Dep. var. & B & SE & $\mathrm{T}$ & $P$ & Interaction \\
\hline \multirow{5}{*}{ GSES } & \multirow{5}{*}{ Country } & Positive mental attitude & -0.04 & 0.07 & -0.59 & 0.552 & $\begin{array}{l}\beta_{P}=0.12(p=0.080) \\
\beta_{S}=0.07(p=0.229)\end{array}$ \\
\hline & & Preventative behaviours & 0.09 & 0.07 & 1.35 & 0.176 & $\begin{array}{l}\beta_{P}=0.09(p=0.217) \\
\beta_{S}=0.21(p<0.001)\end{array}$ \\
\hline & & Proper eating habits & -0.02 & 0.07 & -0.34 & 0.734 & $\begin{array}{l}\beta_{P}=0.09(p=0.209) \\
\beta_{S}=0.06(p=0.317)\end{array}$ \\
\hline & & Pro-health practices & 0.09 & 0.07 & 1.38 & 0.168 & $\begin{array}{c}\beta_{P}=-0.07(p=0.335) \\
\beta_{S}=0.06(p=0.318)\end{array}$ \\
\hline & & IZZ Total & 0.16 & 0.07 & 2.27 & 0.024 & $\begin{array}{c}\beta_{P}=-0.10(p=0.158) \\
\beta_{S}=0.11(p=0.065)\end{array}$ \\
\hline
\end{tabular}

Key: $\beta$ - standardised coefficient Beta; SE - standard error; $p$ - significance; P - Poland; S - Spain. 


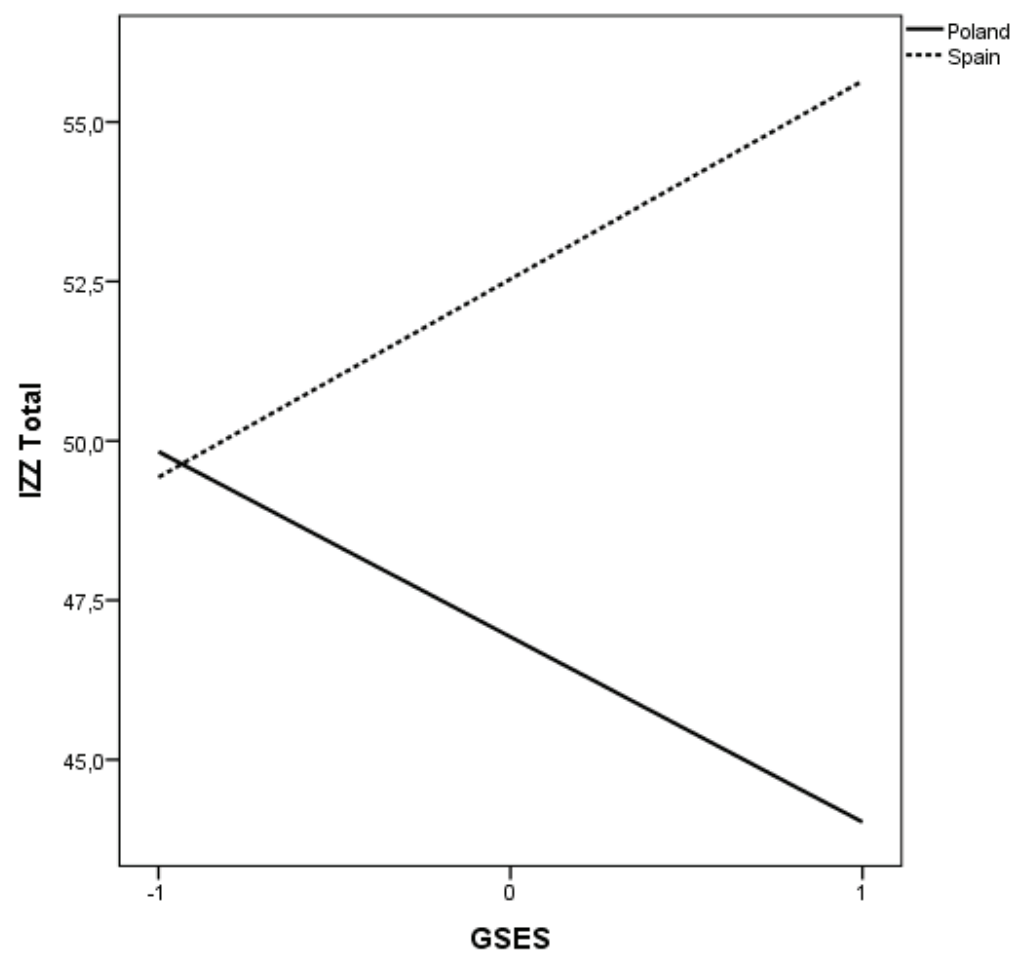

Figure 1. Correlation between sense of self-efficacy and total level of pro-health practices depending on physical education students' home county (Poland vs. Spain)

\section{Discussion}

In the discussed research, some statistically significant relationships were demonstrated between the generalised sense of self-efficacy and the health behaviours. The moderating influence of the students' home country was also statistically significant. The Polish and Spanish physical education students, in among four categories of health-promoting behaviours (positive mental attitude, proper eating habits, preventive behaviours and pro-health practices), obtained the highest results in terms of positive mental attitude (positive thinking, caring for proper relations with others, avoiding negative emotions and mental strain), and so-called pro-health practices (adequate sleep and rest, recreational physical activity, and limiting stimulants). They implemented proper eating habits to a slightly lesser extent, and preventive behaviours also a bit less (compliance with medical recommendations, regular medical check-ups). The demonstrated high level of health-promoting behaviours in the domain of positive mental attitude and the so-called pro-health practices (including recreational physical activity) among physical education students may be associated with the educational profile of the studied group of academic youth oriented toward increased physical activity, which is an important factor contributing to the optimisation of mental state. Relatively high results in the so-called pro-health practices domain (including, but not limited to, physical activity) correspond, at the same time, to trends described in other studies, confirming a higher level of physical activity of physical education students compared to students with a different educational 
profile (Fagaras, Radu, Vanvu, 2015; Bednarek, Pomykała, Bigosińska, Szyguła, 2016; Yager, Gray, Curry, McLean, 2017; Kosiba, Gacek, Wojtowicz, Majer, 2019b). In another study, Spanish physical education students were also characterised by a more healthy lifestyle and more favourable body composition as well as blood lipid profile than students of other university specialisations, which is related to the educational profile focused on promoting an active and healthy lifestyle (Grima, Blay, 2016).

The obtained results also correspond to the tendencies described in other groups of Polish students of teaching specialisations, including physical education, in which it was shown that the students from the University of Physical Education (AWF Kraków), similarly to the students of other specialisations, obtained the highest results in the area of positive mental attitude and less in the category of preventive behaviours (Kosiba et al., 2019b). Similar trends were also described among students of Poznań universities and the Holy Cross University in Kielce, who showed the highest intensity of behaviours associated with positive mental attitude, and less regarding preventive and rational eating behaviours (Rasińska, 2012; Palacz, 2014). Similarly, students of Lublin Medical University mostly applied so-called pro-health practices, and to a lesser degree - preventive behaviours (Kropornicka et al., 2015). The lower level of healthy behaviours in terms of proper eating habits corresponds to the results of other studies among students with different educational profiles, which confirm the prevalence of numerous eating irregularities, in particular: irregular eating and low consumption of products with high nutritional density (vegetables, fruits, whole grain product, cereals, milk and its products). Nutritional irregularities have also been described both among Polish (Myszkowska-Ryciak, Kraśniewska, Harton, Gajewska, 2011; Rasińska, 2012; Misiarz Malczyk, ZołoteńkaSynowiec, Rydelek, Sobota, 2013; Szczodrowska, Krysiak, 2013; Grygiel-Górniak et. al., 2016), as well as in Chinese, Brazilian, Spanish and American students (Hu et al., 2016; Alvarenga Mdos, Lourenço, Philippi, Scagliusi, 2013; Navarro-Gonzalez, Periago-Caston, Vidana-Gaytan, Rodriguez-Tadeo, 2019; Yahia, Wang, Rapley, Dey, 2016). Insufficient vegetable consumption among students has also been confirmed in a systematic review of works from 2009-2018 (Rodrigues et al., 2019).

Regarding the future professional work of the physical education students surveyed, it can be assumed that students who present a higher level of pro-health behaviours would more effectively influence the development of pro-health attitudes in their students. This is suggested by the results of research in the USA which showed the importance of teachers' positive attitudes towards nutrition for the adoption of students' eating habits (Findholt et al., 2016; Rossiter et al., 2007). In this context, it seems extremely important to take actions conducive to rationalising food choices and other aspects of the lifestyle in physical education students, who, in their future work will be involved in the implementation of health education among children and youth.

In the authors' research, statistically significant positive correlations have been shown between the generalised sense of self-efficacy and the intensity of positive mental attitudes and preventive behaviours among Polish and Spanish physical education students. The found regularities are explained in the characteristics of the analysed dimension of personality and refer to the results of studies by other authors. Higher levels of healthy behaviours in terms of positive mental attitude and preventive behaviours among students with a high sense of self-efficacy may be associated with their belief in the possibility of achieving specific goals, such as health, by exercising control over health determinants, holistically defined as striving for psychophysiological balance. As well as being a friendly environment, a healthy lifestyle denotes a genetic capability and the availability of medical care, a basic determinant of health (WHO, 2004; Gray, 2017). In another study on Polish university students, a positive impact has been demonstrated regarding positively correlated psychological traits, including a sense of self-efficacy, coherence, 
and optimism on students' pro-health behaviours (Posadzki, Stockl, Musonda, Tsouroufli, 2010). In a Turkish study, a relationship has also been found between locating a sense of health control and a sense of healthrelated efficacy, as well as student pro-health behaviours (Açıkgöz Çepni, Kitiş, 2017). The predictive importance of a generalised sense of self-efficacy on the scale of pro-health behaviours has also been confirmed among Japanese and Chinese students (Sato, 2017; Xu et al., 2017). In M. Lipowski's research (2012), a positive correlation between the level of optimism and the level of efficacy and some health behaviours of women practicing sports was found. The predictive importance of a generalised sense of self-efficacy on the level of physical activity has been confirmed among Chinese, Malaysian, British, South Korean and Australian high-school students (Chung-Yan, 2014; Ler, Wee, Ling, 2017; Blake, Stanulewicz, Mcgill, 2017; Lee, Park, Lee, Kim, Park, 2018; Plotnikoff, Costigan, Karunamuni, Lubans, 2013). Unlike the results obtained in this study which did not show a correlation between the level of self-efficacy and the intensity of proper eating habits among physical education students, other studies have shown a larger scale of rational dietary choices with a high level of effectiveness. Such trends have been described, among others, for people practicing sport, including juniors training football, Polish American football players, athletes practicing individual disciplines (Gacek, Frączek, 2013; Gacek, 2015; Gacek, 2019) and women recreationally undertaking fitness (Gacek, 2017), as well as professional soldiers (Gacek, 2018). Different trends in this area may result from the limited number of diagnostic questions regarding diet in the Inventory of Health Behaviours by Z. Juczyński (2012), who themselves suggest the need for further in-depth research.

The modern holistic concept of health emphasizes the key importance of a healthy lifestyle, not only for strengthening health potential, but also for improving quality of life. In studies among students of teaching faculties, it has been shown that adolescents with a greater intensity of healthy behaviours (in terms of positive mental attitude, daily pro-health practices, proper eating habits, and preventive behaviours) were also characterised by a higher level of life satisfaction (Kosiba, Gacek, Bogacz-Walancik, Wojtowicz, 2017).

Referring to the results indicating positive relationships between a generalised sense of self-efficacy and health-promoting behaviours, it should be pointed out that strengthening one's own efficacy, including through psychological techniques, may promote a healthy lifestyle and in consequence strengthening the health, which has been confirmed by British authors (Ashford, Edmunds, French, 2010).

The results obtained in this study on the moderating impact of the home country (Poland vs. Spain) in relation to the studied dependencies (sense of efficacy vs. the level of pro-health behaviours), showed that the country of origin can be considered a moderator of the self-efficacy relationship with the general indicator of health-oriented behaviours, but only among the physical education students from Spain, where the higher the intensity of the generalised sense of self-efficacy, the higher the overall level of health-promoting behaviours. This was different from the students from Poland, in whom the overall level of health behaviours decreased as the sense of self-efficacy increased. Assuming that personality is an intercultural trait, the relationships between pro-health behaviours and personality traits in different cultures could be the same. There are no publications in literature on the moderating importance of the country of origin in relation to the studied dependency of efficacy vs. pro-health behaviours. There are systematic reviews regarding the determinants of physical activity, but they did not clearly identify the moderators of the relationship between personality and physical activity (Wilson, Dishman, 2015). Perhaps the special emphasis on health education from an early age in Spain (written in the decrees of individual autonomous communities) positively moderates the relationship between the generalised sense of self-efficacy and the intensity of health-promoting behaviours. In other studies aiming to compare the health behaviours of Polish and Spanish 
physical education students (Gdańsk vs. Murcia), the differences between some aspects of lifestyle was confirmed, where Spanish students showed a higher level of physical activity and consumed more seafood and dairy products, less often reaching for sweetened sodas and alcoholic beverages or tobacco. In turn, Polish students consumed more vegetables and liquids. Regardless of the students' country of origin, it has been suggested to rationalise student lifestyle in a way that promotes early prevention of chronic diseases, such as obesity and diabetes (LopezSanchez et al., 2019). These lifestyle differences can originate in different cultures, traditions and climatic factors (Northern vs. Southern Europe), and also from the implementation of effective health policies (Lopez-Sanchez et al., 2019). The cited authors also indicate the need for repeating research in various regions of Poland and Spain, something which was attempted in this study.

Further research on the psychological determinants of health behaviours among physical education students should consider a broader spectrum of the group (also other years and levels of study) and a larger number of analysed variables.

\section{Conclusion}

1. Polish and Spanish physical education students, among the pro-health behaviours included in the IZZ, obtained the highest scores in the category of positive mental attitude, lower in terms of pro-health practices and proper eating habits, and less again in the domain of preventive behaviours.

2. Statistically significant relationships between the level of the generalised sense of self-efficacy and the intensity of certain categories of pro-health behaviours (positive mental attitude and preventive behaviours) have been demonstrated among Polish and Spanish physical education students.

3. Among Polish and Spanish physical education students, the moderating influence of their home country on the relationships between the generalised sense of self-efficacy and the general indicator of pro-health behaviours have been demonstrated, with an increase in the scale of pro-health behaviours along with the intensification of the generalised sense of self-efficacy among the Spanish students and a reduction in the Polish students.

\section{References}

Açıkgöz Çepni, S., Kitiş, Y. (2017). Relationship between healthy lifestyle behaviors and health locus of control and health-specific selfefficacy in university students. Japan Journal of Nursing Science, 14 (3), 231-239. DOI: 10.1111/jjns.12154.

Alvarenga Mdos, S., Lourenço, B.H., Philippi, S.T., Scagliusi, F.B. (2013). Disordered eating among Brazilian female college students. Cadernos de Saúde Pública, 29 (5), 879-888.

Ashford, S., Edmunds, J., French, D.P. (2010). What is the best way to change self-efficacy to promote lifestyle and recreational physical activity? A systematic review with meta-analysis. British Journal of Health Psychology, 15 (Pt 2), 265-288. DOI: 10.1348/135910709X461752.

Bednarek, J., Pomykała, S., Bigosińska, M., Szyguła, Z. (2016). Physical activity of Polish and Turkish university students as assessed by IPAQ. European Journal of Sport Sciences and Medicine, 16 (4), 13-22. DOI: 10.18276/cej.2016.4-02.

Blake, H., Stanulewicz, N., Mcgill, F. (2017). Predictors of physical activity and barriers to exercise in nursing and medical students. Journal of Advanced Nursing, 73 (4), 917-929. DOI: 10.1111/jan.13181.

Chang, L.C., Liao, L.L., Chen, M.I., Niu, Y.Z., Hsieh, P.L. (2017). Strengthening teachers' abilities to implement a vision health program in Taiwanese schools. Health Education Research, 32 (5), 437-447. http://doi.org/10.1093/her/cyx057.

Chung-Yan, C.J. (2014). Psychological determinants of exercise behavior of nursing students. Contemorary Nurse, 49 (1), 60-67. DOI: 10.1080/10376178.2014.11081954.

Deasy, C., Coughlan, B., Pironom, J., Jourdan, D., Mcnamara, P.M. (2015). Psychological distress and lifestyle of students: implications for health promotion. Health Promotion International, 30 (1), 77-87. DOI: 10.1093/heapro/dau086. 
Decreto 97/2015 de 3 de marzo, por El que se establece la ordenacion y las ensenanzas correspondientes a la Educacion Primaria en la Comunidad Autonoma de Andalucia, in: Ensenanzas propias de la Comunidad Autonoma de Andalucia para la Educacion Primaria.

Fagaras, S.P., Radu, L.E., Vanvu, G. (2015). The level of physical activity of university students. Procedia Social and Behavioral Sciences, 197, 1454-1457. DOI: 10.1016/j.sbspro.2015.07.094.

Findholt, N.E., Izumi, B.T., Shannon, J., Nguyen, T. (2016). Food-related practices and beliefs of rural US elementary and middle school teachers. Rural and Remote Health, 16 (2), 3821.

Gacek, M., Frączek, B. (2013). Nutritional evaluation of junior football players depending on the global level of self-efficacy of the athletes. Medicina Sportiva, 17 (2), 72-75.

Gacek, M. (2015). Association between self-efficacy and dietary behaviors of American football players in the Polish clubs in the light of dietary recommendations for athletes. Roczniki Panstwowego Zakładu Higieny, 66 (4), 361-366.

Gacek, M. (2016). Poczucie własnej uogólnionej skuteczności a wybory żywieniowe młodych kobiet rekreacyjnie uprawiających fitness. Medycyna Ogólna i Nauki o Zdrowiu, 22 (3), 179-183.

Gacek, M. (2017). The sense of life satisfaction versus dietary choices of young women doing fitness for recreational purposes. Roczniki Panstwowego Zakładu Higieny, 68 (1), 77-81.

Gacek, M. (2018). Poczucie własnej uogólnionej skuteczności a wybrane aspekty stylu życia grupy żołnierzy zawodowych. Hygeia Public Health, 53 (1), 79-84.

Gacek, M. (2019). Selected personal conditions determining the frequency of consuming groups of products among athletes professionally training individual sport disciplines. Human Movement, 20 (3), 56-65. DOI: 10.5114/hm.2019.77836.

Grey, M. (2017). Lifestyle determinants of health: Isn't it all about genetics and environment? Nursing Outlook, 65 (5), 501-505. DOI: 10.1016/j.outlook.2017.04.011.

Grima, J.S., Blay, M.G. (2016). Perfil cardiovascular en estudiantes de Ciencias de la Actividad Física y del Deporte, estudiantes de otras disciplinas y trabajadores en activo. Medicina General y de Familia, 5, 9-14. DOI: 10.1016/j.mgyf.2015.12.006.

Grygiel-Górniak, B., Tomczak, A., Krulikowska, N., Przysławski, J., Seraszek-Jaros, A., Kaczmarek, E. (2016). Physical activity, nutritional status, and dietary habits of students of a medical university. Sport Science for Health, 12 (2), 261-267. DOI: 10.1007I s11332-016-0285-x.

http://www.fao.org/nutrition/education/food-dietary-guidelines/regions/europe/en.

Hu, P., Huang, W., Bai, R., Zhang, F., Sharma, M., Shi, Z., Xiao, X., Abdullah, A.S., Zhao, Y. (2016). Knowledge, attitude, and behaviors related to eating out among University Students in China. International Journal of Environmental Research and Public Health, 13 (7), pii: E696.

Juczyński, Z. (2012). Narzędzia pomiaru w promocji i psychologii zdrowia. Warszawa: Pracownia Testów Psychologicznych.

Kosiba, G., Gacek, M., Bogacz-Walancik, A., Wojtowicz, A. (2016a). The lifestyle of students - future teachers. Antopomotoryka. Journal of Kinesiology and Exercise Sciences, 74 (26), 83-94. DOI: 10.5604/01.3001.0009.5616.

Kosiba, G., Gacek, M., Wojtowicz, A., Bogacz-Walancik A. (2016b). Health-related behaviours, physical activity and perceived life satisfaction in the academic youth of pedagogical subjects in Cracow. Studies in Sport Humanities, 20, 6-15.

Kosiba, G., Gacek, M., Bogacz-Walancik, A., Wojtowicz, A. (2017). Zachowania prozdrowotne a satysfakcja zżycia studentów kierunków nauczycielskich. Teraźniejszość - Człowiek - Edukacja, 2 (78), 79-93.

Kosiba, G., Gacek, M., Wojtowicz, A. (2019a). Readiness to change and pro-health behaviours among students of physical education and other teaching specialisations. Central European Journal of Sport Sciences and Medicine, 4, 53-65.

Kosiba, G., Gacek, M., Wojtowicz, A., Majer, M. (2019b). Level of knowledge regarding health as well as health education and prohealth behaviours among students of physical education and other teaching specialization. Baltic Journal of Health and Physical Activity, 11 (1), 83-95. DOI: 10.29359/BJHPA.11.1.0.

Kropornicka. B., Baczewska, B., Dragan, W., Krzyżanowska, E., Olszak, C., Szymczuk, E. (2015). Zachowania zdrowotne studentów Uniwersytetu Medycznego w Lublinie w zależności od miejsca zamieszkania. Rozprawy Społeczne, 9 (2), 58-64.

Lee, C.G., Park, S., Lee, S.H., Kim, H., Park J.W. (2018). Social cognitive theory and physical activity among Korean Male High-School Students. American Journal of Men's Health, 12 (4), 973-980. DOI: $10.1177 / 1557988318754572$.

Ler, H.Y., Wee, E.H., Ling, S.K. (2017). Differences in psychosocial determinants by gender and physical activity index among undergraduates. Journal of Sport Psychology, 26 (4), 127-131.

Lipowski, M. (2012). Level of optimism and health behavior in athletes. Medical Science Monitor, 18 (1), 39-43. DOI: 10.12659/ MSM.882200. 
Lopez-Sanchez, G.F., Radzimirski, Ł., Skalska, M., Jastrzębska, J., Smith, L., Wakuluk D., Jastrzębski, Z. (2019). Body composition, physical fitness, physical activity and nutrition in Polish i Spanish male students of sports sciences: differences and correlations. International Journal of Environmental Research and Public Health, 16 (7), pii: E1148. DOI: 10.3390/ijerph16071148.

Misiarz, M., Malczyk, E., Zołoteńka-Synowiec, M., Rydelek, J., Sobota, O. (2013). Ocena zachowań żywieniowych studentów kierunków medycznych i niemedycznych z województwa świętokrzyskiego. Pielęgniarstwo i Zdrowie Publiczne, 3 (3), 265-272.

Monhollen, C., Summers, L., Sabin, M., Rutherford, J. (2016). Sedentary behaviors and physical activity in relation to class standing in university students. Medicine \& Science in Sports \& Exercise, 48 (5S), 1063. DOI: 10.1249/01.mss.0000488198.25704.eb.

Montenegro, E., Salinas, J., Parra, M., Lera, L., Vio, F. (2014). Evaluation of a nutrition education intervention in teachers and students in pre-school and primary schools in los Andes, Chile. Archivos Latinoamericanos de Nutrición, 64 (3), 182-191.

Moynihan, S., Paakkari, L., Välimaa, R., Jourdan, D., Mannix-McNamara, P. (2015). Teacher competencies in health education: Results of a delphi study. PLoS ONE, 10 (12), e0143703. DOI: 10.1371/journal.pone.0143703.

Myszkowska-Ryciak, J., Kraśniewska, A, Harton, A., Gajewska, D. (2011). Porównanie wybranych zachowań żywieniowych studentek Akademii Wychowania Fizycznego i Szkoły Głównej Gospodarstwa Wiejskiego. Problemy Higieny i Epidemiologii, 92 (4), 931-934.

Navarro-Gonzalez, I., Periago-Caston, M., Vidana-Gaytan, M., Rodriguez-Tadeo, A. (2019). Food neophobia and heating disorders: Imapct on adherence to the Mediterranean diet of Spanish university students. Revista Chilena de Nutricion, 46 (2), 174-180. DOI: 10.4067/S0717-75182019000200174.

Palacz, J. (2014). Zachowania zdrowotne studentów w świetle wybranych uwarunkowań Medycyna Ogólna i Nauki o Zdrowiu, 20 (3), 301-306. DOI: 10.5604/20834543.1124662.

Plotnikoff, R.C., Costigan, S.A., Karunamuni, N., Lubans, D.R. (2013). Social cognitive theories used to explain physical activity behavior in adolescents: a systematic review and meta-analysis. Preventive Medicine, 56 (5), 245-253. DOI: 10.1016/j.ypmed.2013.01.013.

Posadzki, P., Stockl, A., Musonda, P., Tsouroufli, M. (2010). A mixed-method approach to sense of coherence, health behaviors, selfefficacy and optimism: towards the operationalization of positive health attitudes. Scandinavian Journal of Psychology, 51 (3), 246-252. DOI: DOI: 10.1111/j.1467-9450.2009.00764.x.

Rasińska, R. (2012). Nawyki żywieniowe studentów w zależności od płci. Nowiny Lekarskie, 81 (4), 354-359.

Remick, A.K., Polivy, J., Pliner, P. (2009). Internal and external moderators of the effect of variety on food intake. Psychological Bulletin, 135 (3), 434-451. DOI: 10.1037/a0015327.

Rodrigues, V.M, Bray, J., Fernandes, A.C., Bernardo, G.L., Hartwell, H, Martinelli, S.S., Uggioni, P.L., Cavalli, S.B., Proenca, R.P.D. (2019). Vegetable consumption and factors associated with increased intake among college students: A scoping review of the Last 10 Years. Nutrients, 11 (7). DOI: 10.3390/nu11071634.

Rossiter, M., Glanville, T., Taylor J., Blum, I. (2007). School food practices of prospective teachers. Journal of School Health, 77 (10), 694-700. DOI: 10.1111/j.1746-1561.2007.00253.x

Ordinance of the Minster of National Education from 14 Feb. 2017 regarding the core-curriculum of pre-school education and the corecurriculum of general education for primary schools, including students with moderate or severe mental disabilities, general education for $1^{\text {st }}$ degree trade schools, general education for specials schools preparing for professional work and general education for post-secondary schools (Journal of Laws 2017, item 356).

Ordinance of the Minster of National Education from 30 Jan. 2018 regarding the core-curriculum of general education for secondary schools, technical schools and $2^{\text {nd }}$ degree trade schools] (Journal of Laws 2018, item 467).

Sato, K. (2017). Behavioural changes among university students examined using physical activity monitor. Nihon Eiseigaku Zasshi, 72 (3), 184-191. DOI: 10.1265/jjh.72.184.

Schee, C.V., Gard, M. (2014). Healthy, happy and ready to teach, or why kids can't learn from fat teachers; the discursive politics of school reform and teacher health. Critical Public Health, 24 (2), 210-225.

Szczodrowska, A., Krysiak, W. (2013). Analiza wybranych zwyczajów żywieniowych oraz aktywności fizycznej studentów łódzkich szkół wyższych. Problemy Higieny i Epidemiologii, 94 (3), 518-521.

Wilson, K.E., Dishman, R.K. (2015). Personality and physical activity: A systematic review and meta-analysis. Personality and Individual Differences, 72, 230-242. DOI: 10.1016/j.paid.2014.08.023.

World Health Organization (2004). Global Strategy on Diet, Physical Activity and Health. WHO; Geneva, Switzerland.

Xu, X., Pu, Y., Sharma, M., Rao, Y., Cai, Y., Zhao, Y. (2017). Predicting physical activity and healthy nutrition behaviors using social cognitive theory: Cross-sectional survey among undergraduate students in Chongqing, China. International Journal of Environmental Research and Public Health, 14 (11), pii: E1346. DOI: 10.3390/ijerph14111346. 
Yager, Z., Gray, T., Curry, C., McLean, S.A. (2017). Body dissatisfaction, excessive exercise, and weight change strategies used by first-year undergraduate students: comparing health and physical education and other education students. International Journal of Eating Disorders, 5, 10. DOI: 10.1186/s40337-016-0133-z.

Yahia, N., Wang, D., Rapley, M., Dey, R. (2016). Assessment of weight status, dietary habits and beliefs, physical activity, and nutritional knowledge among university students. Perspectives Public Health, 136 (4), 231-244. DOI: 10.1177/1757913915609945.

Cite this apticle aS: Gacek, M., Kosiba, G., Wojtowicz, A. (2020). Sense of Generalised Self-efficacy and Pro-health Behaviours of Polish and Spanish Physical Education Students. Central European Journal of Sport Sciences and Medicine, 3 (31), 95-105. DOI: 10.18276/cej.2020.3-08. 